\title{
40. OXYGEN ISOTOPE INVESTIGATIONS OF ROCKS OF LEG 37
}

\author{
S. Hoernes and H. Friedrichsen, Institüt für Mineralogie, \\ Universität Tubingen, Tubingen, West Germany
}

\begin{abstract}
The $\delta^{18} \mathrm{O}$ of 28 analyzed whole-rock samples of Leg 37 (mainly Hole $332 \mathrm{~A}$ ) is in the range of +4.9 to $6.5 \%$ relative to SMOW.

The lower $\delta$-values were probably produced by reaction with seawater. These data indicate a tendency to higher $\delta$-values with increasing depth.

Oxygen isotope data are given for separated minerals from 16 samples, mainly plagioclase $\left(\delta^{18} \mathrm{O}=5.4\right.$, mean of 18 values $)$, magnetite $\left(\delta^{18} \mathrm{O}=3.0\right.$, mean of 11 values $)$, olivine $\left(\delta^{18} \mathrm{O}=4.2,4.3\right.$, $4.5)$, pyroxene $\left(\delta^{18} \mathrm{O}=3.0,5.6\right)$, antigorite $\left(\delta^{18} \mathrm{O}=2.3\right)$, and hornblende $\left(\delta^{18} \mathrm{O}=3.9,4.3\right)$.

Oxygen isotopic fractionations between magnetite and plagioclase are in the range of $1.8 \%$ to $3.5^{\circ} \% 0$, suggesting equilibrium temperatures between $1180^{\circ}$ and $840^{\circ} \mathrm{C}$ (formation temperatures of the rocks).
\end{abstract}

\section{INTRODUCTION}

Oxygen isotope fractionations between cogenetic minerals of basalts, gabbros, and peridotites of the oceanic crust give us an understanding of the equilibrium temperatures (temperatures of the last equilibration) during the uplift at the middle-oceanic rifts. The isotopic composition of these rocks should be very close to the whole-rock composition of the mantle, if no exchange with ocean water occurs. Any interaction with ocean water at higher temperatures $\left(>200^{\circ} \mathrm{C}\right)$ should lower the isotopic composition (enrichment in ${ }^{16} \mathrm{O}$ ) in the silicate phases.

It was the aim of this investigation to get information on the reactions, which take place during the uplift of the oceanic crust and the temperatures of the mineral reactions in these rocks. These temperatures reflect the amount and origin of fluid phases, which were present in the magma during the reaction.

\section{EXPERIMENTAL PROCEDURE}

Most phenocrysts (plagioclase, olivine) have been separated by hand-picking. The magnetic separator was used for separating the fine-grained plagioclases of the groundmass after removing the plagioclase phenocrysts by hand-picking.

Magnetite was separated from fractions finer than $0.037 \mathrm{~mm}$ using a small hand-magnet.

Fine-grained mineral fractions were checked for impurities by microscope and X-ray diffraction.

The oxygen was extracted from 20 to $30 \mathrm{mg}$ portions of the separated minerals and 30 to $40 \mathrm{mg}$ of the powdered whole-rock samples using the bromine pentafluoride procedure (Clayton and Mayeda, 1963). The mass-spectrometric analyses were carried out with a $60^{\circ}, 15-\mathrm{cm}$ single focusing mass spectrometer.
The $\delta$-SMOW-values given in this paper are based on NBS 20 as a comparing standard, but if we calculate our SMOW-values with TSS (J.R. O'Neil, personal communication) as a working standard, our SMOWvalues are $0.35 \%$ too low.

\section{RESULTS}

Whole-rock data are presented in Figure 1 (see also Table 1). These data indicate a trend to higher $\delta$-values with increasing depth. If the mantle is the only source for the oxygen in the silicates, we would assume that the $\delta$-values of the basalts should scatter only in a very narrow range $\left(\max \pm 0.5^{\circ} \% 0\right)$, if the mantle is homogeneous as far as the oxygen isotope composition is concerned. The scattering of the whole-rock data obviously indicates reactions with an oxygen reservoir of different isotopic composition. On the basis of the $\delta^{18} \mathrm{O}$ values, we could assume that there are three units, each of them with lower $\delta^{18} \mathrm{O}$ values in the upper part, indicating the different volcanic activities. The lower $\delta^{18} \mathrm{O}$ values on the top of each unit are caused by interaction with seawater, which was obviously more intensive in the upper parts of the different layers.

The difference between top and bottom of the layers of $1 \%$ can be used for a rough calculation of the amount of oxygen in the solid phases derived from seawater, which is in the range of $10 \%$ to $20 \%$.

The mean $\delta^{18} \mathrm{O} /{ }^{16} \mathrm{O}$ ratio of 28 basalts is $5.9^{\circ}$ \%o corresponding to the value given by Taylor (1968) for unaltered basalts and also to values reported from lunar basalts (Epstein and Taylor, 1970; Onuma et al., 1970).

Mineral data are presented in Table 2. The temperatures are derived from the experimentally determined magnetite-water curve of Bertenrath et al. (1973), and the plagioclase-water curve of O'Neil and Taylor (1967) (Figure 2). Most mineral analyses have been carried out twice; some magnetite data are de- 


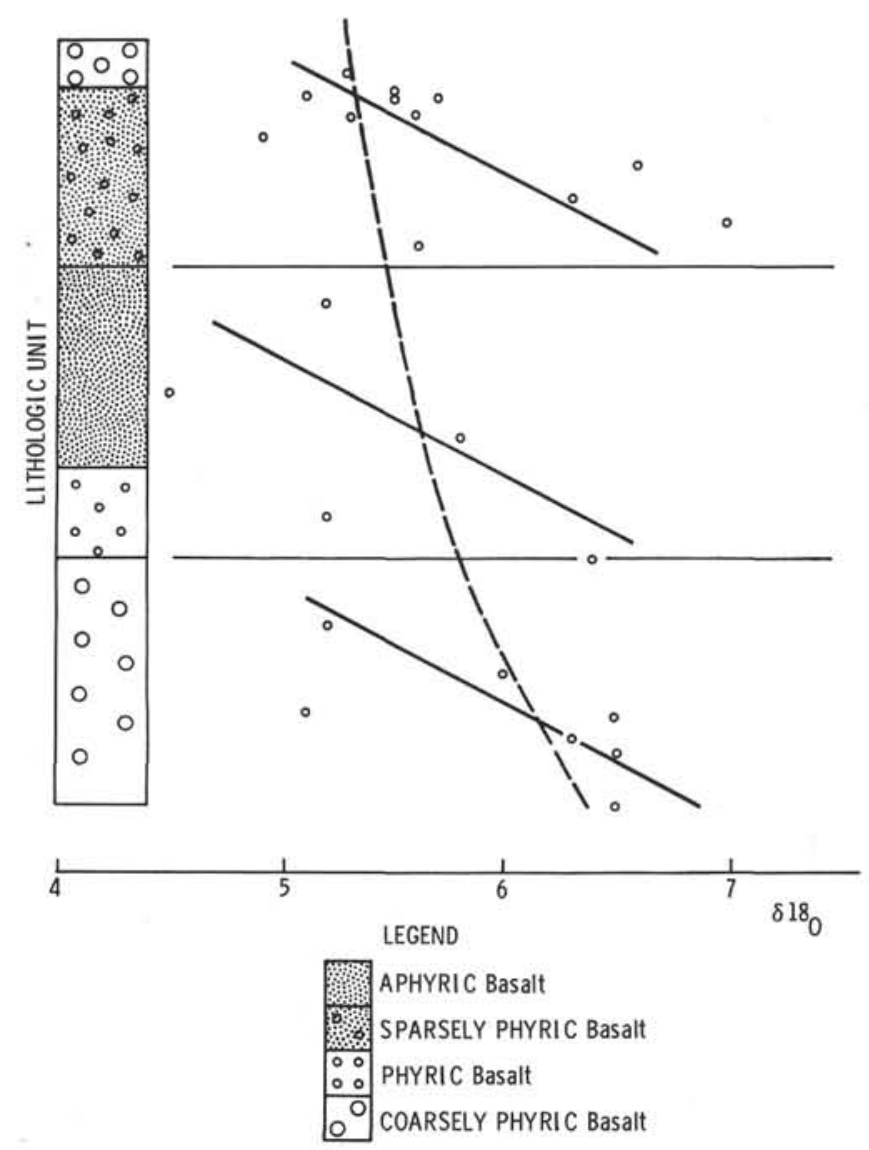

Figure 1. Whole rock isotopic data for Leg 37 basalts.

rived from a single analysis, because of the very small content of magnetite in these samples.

Investigations on the magnetic properties of Leg 37 rocks carried out in Bochum (Bleil and Peterson, this volume) showed that magnetite in some samples from Hole $332 \mathrm{~A}$ is partly replaced by maghemite. This oxidation seems to have no influence on the $\delta^{18} \mathrm{O}$ of the magnetite.

Seven magnetite samples have been checked by X-ray (with Guinier camera) for the maghemite content. Magnetite and maghemite were found in Samples $332 \mathrm{~A}-7-1,66-68 \mathrm{~cm}, 332 \mathrm{~B}-10-3,47-50 \mathrm{~cm}, 333 \mathrm{~A}-10-2$, 64-65 cm, 333A-10-3, 5-6 cm, and 334-26-1, 133-144 $\mathrm{cm}$; magnetite as the only phase in Samples 332B-47-2, $118-121 \mathrm{~cm}$, and $333 \mathrm{~A}-10-2,64-65 \mathrm{~cm}$; and maghemite in Sample 332A-11-1, $84-86 \mathrm{~cm}$.

There seems to be no correlation between maghemite content and the temperature derived from magnetite (maghemite)-plagioclase fractionations (see Table 2).

Figure 2 shows the "Concordancy diagram" after Anderson et al. (1971) with temperatures resulting from the magnetite-water curve of Bertenrath (1973). The differences of the $\delta$-values between plagioclase and magnetite $(\Delta \mathrm{plag} / \mathrm{mag})$ of Samples $332 \mathrm{~A}-7-1,66-68 \mathrm{~cm}$, $332 \mathrm{~A}-40-1,62-64 \mathrm{~cm}, 332 \mathrm{~B}-10-3,47-50 \mathrm{~cm}, 332 \mathrm{~B}-47-2$, $118-121 \mathrm{~cm}, 333 \mathrm{~A}-10-2,64-65 \mathrm{~cm}$, and $334-26-1,133-$ $144 \mathrm{~cm}$ are equivalent to those of other terrestrial basalts and also to lunar basalts. The equilibrium temperature of these rocks, which is the crystallization
TABLE 1

Whole Rock Data

Sample

Depth $(\mathrm{m}) \quad \begin{gathered}\text { Sample } \\ \text { (Interval in } \mathrm{cm})\end{gathered} \delta^{18} \mathrm{O} /{ }^{16} \mathrm{O}$ SMOW $(\%)$

Hole 332A

100

$\begin{array}{ll}6-2,107-109 & +5.3 \\ 7-1,20-22 & +5.5 \\ 7-1,66-68 & +5.5 \\ 7-1,106-108 & +5.1 \\ 7-1,123-125 & +5.7 \\ 8-1,50-52 & +5.6 \\ 8-2,90-92 & +5.3 \\ 9-1,95-97 & +4.9 \\ 10, C \mathrm{C} & +6.6 \\ 12-1,81-83 & +6.3 \\ 13-1,144-146 & +7.0 \\ 14-1,101-103 & +5.6 \\ 17-1,95-97 & +5.2 \\ 21-1,101-103 & +4.5 \\ 23-1,130-132 & +5.8 \\ 27-1,4-6 & +5.2 \\ 29-1,65-66 & +6.4 \\ 32-2,28-30 & +5.2 \\ 34-2,36-38 & +6.0 \\ 36-2,5-7 & +4.9 \\ 36-2,23-25 & +6.5 \\ 37-1,118-120 & +6.3 \\ 37-1,101-103 & +6.2 \\ 38-1,144-146 & +6.5 \\ 40-3,35-37 & +6.5\end{array}$

Site 335

\begin{tabular}{lcc}
450 & $5-2,48-50$ & +5.6 \\
467 & $7-1,8-10$ & +5.6 \\
539 & $14-4,130-143$ & +4.9 \\
\hline
\end{tabular}

temperature of the groundmass (because magnetite is always part of the groundmass), is between $1000^{\circ}$ and $1180^{\circ} \mathrm{C}$. The same temperatures $>1000^{\circ} \mathrm{C}$ can be derived from $\Delta$ plagioclase-olivine in Samples 333A-10-2, $64-65 \mathrm{~cm}$ and $332 \mathrm{~A}-40-1,62-64 \mathrm{~cm}$ which is 1.0 and 1.2 , respectively. These values agree with the data of Anderson et al., 1971. The $\Delta$ plagioclase-olivine of $0.4 \%$ of Sample 332B-35-1, 142-144 cm indicates a nonequilibrium condition.

The equilibration temperatures for the oxygen isotopes (i.e., crystallization temperature) of the few plutonic rocks analyzed fall within the field of gabbros shown in Figure 2.

Sample 334-22-1, 17-23 cm from Site 334 contains two generations of hornblende, a dark (primary?) and a light green (secondary) one, which could be separated. These minerals yield different $\delta$-values $(4.3 \%$ oo the primary, $3.9^{\circ} \%$ o the secondary). The $\Delta$-plagioclase-secondary hornblende of $2.0 \%$ corresponds to the value given by Taylor (1968) for a hornblende gabbro.

We have not yet been able to determine if the dark brown hornblende is a reaction product with primary (juvenile) water. The hydrogen isotopic composition should give us further information on this question.

It is very interesting that the oxygen isotope fractions between minerals of some basalts yield temperatures (derived from the $\Delta$-magnetite-plagioclase fractionation) close to the values for plutonic rocks. 
TABLE 2

Mineral Data

\begin{tabular}{|c|c|c|c|c|c|c|c|c|c|}
\hline $\begin{array}{c}\text { Sample } \\
\text { (Interval in } \mathrm{cm} \text { ) }\end{array}$ & $\begin{array}{l}\text { Plagioclase } \\
\text { Pheno. }\end{array}$ & Ground & $\mathrm{Px}$ & $\mathrm{Ol}$ & Mt & Serp & $\mathrm{Hbl}$ & $\Delta$ & $\mathrm{T}\left({ }^{\circ} \mathrm{C}\right)$ \\
\hline $332 \mathrm{~A}-7-1,66-68$ & & & & & & & & & \\
\hline $\begin{array}{l}\text { Basalt } \\
332 \mathrm{~A}-11-1,84-86\end{array}$ & 5.4 & 5.9 & & & 4.1 & & & m-pl 1.8 & 1180 \\
\hline $\begin{array}{l}\text { Basalt } \\
\text { 332A-14-1, 36-38 }\end{array}$ & & 5.6 & & & 2.3 & & & m-pl 3.3 & 880 \\
\hline $\begin{array}{l}\text { Basalt } \\
332 \mathrm{~A}-32-2,74-76\end{array}$ & 6.5 & & & & 3.0 & & & m-pl 3.5 & 840 \\
\hline Basalt & 5.8 & & & & & & & & \\
\hline $\begin{array}{l}332 \mathrm{~A}-40-1,62-64 \\
\text { Basalt }\end{array}$ & 5.5 & & & 4.3 & 3,6 & & & $\begin{array}{l}\text { m-pl } 1.9 \\
\text { pl-ol } 1.2\end{array}$ & 1150 \\
\hline $\begin{array}{l}\text { 332B-2-1, 48-51 } \\
\text { Basalt }\end{array}$ & 5.2 & & & & & & & & \\
\hline $\begin{array}{l}\text { 332B-2-5, 136-139 } \\
\text { Basalt } \\
332 \mathrm{~B}-10-3,47-50\end{array}$ & 4.9 & & & & & & & & \\
\hline $\begin{array}{l}\text { Basalt } \\
\text { 332B-35-1, 142-144 }\end{array}$ & & 5.5 & & & 3.4 & & & m-pl 2.1 & 1100 \\
\hline $\begin{array}{l}\text { Basalt } \\
\text { 332B-47-2, 18-121 }\end{array}$ & & 4.9 & & 4.5 & 2.2 & & & m-pl 2.7 & 950 \\
\hline $\begin{array}{l}\text { Basalt } \\
333 \mathrm{~A}-10-2,64-65\end{array}$ & & 5.3 & & & 3.2 & & & m-pl 2.5 & 1000 \\
\hline $\begin{array}{c}\text { Basalt } \\
333 \mathrm{~A}-10-3,5-6\end{array}$ & 5.3 & 5.2 & & 4.2 & 2.7 & & & $\begin{array}{l}\text { pl-ol } 1.0 \\
\text { bl-pl } 1.9\end{array}$ & 1150 \\
\hline $\begin{array}{l}\text { Basalt } \\
334-22-1,17-23\end{array}$ & 5.1 & 5.4 & & & 3.5 & & (sec) 3.9 & hbl-pl 2.0 & \\
\hline $\begin{array}{l}\text { Gabbro } \\
334-22-2,110-120\end{array}$ & 5.9 & & & & & & (pri) 4.3 & hbl-pl 1.6 & \\
\hline $\begin{array}{l}\text { Gabbro } \\
334-25-1,52-58\end{array}$ & 5.6 & & & & & & & & \\
\hline $\begin{array}{c}\text { Peridotite } \\
334-26-1,133-144\end{array}$ & & & 3.0 & & 0.4 & & & $\mathrm{~m}-\mathrm{px} 2.6$ & 820 \\
\hline Peridotite & 3.9 & & & & 1.1 & 2.3 & & & \\
\hline
\end{tabular}

Since there are also aphyric and coarse-grained basalts in this group, the cooling rate seems to be not the only controlling factor. Postmagmatic alterations of the oxygen isotope composition cannot be excluded.

Partial remelting with higher partial pressures of $\mathrm{H}_{2} \mathrm{O}$ than those in the primary basalts could be a possibility to explain the relatively low temperatures of equilibration. However, since no hydrous phases are found in the basalts, water pressures were presumably low. Further investigations are needed before a definitive statement can be made.

\section{REFERENCES}

Anderson, A.T., Clayton, R.N. and Mayeda, T.K., 1971. Oxygen isotope thermometry of Mafic Igneous Rocks. J. Geol., v. 79, p. 715-729.

Bertenrath, R., 1973. Die Sauerstoffisotopenfraktionierung zwischen Magnetit und Wasser-Ihre Bedeutung als geologisches Thermometer: Dissertation, Universität Marburg.

Bertenrath, R., Friedrichsen, H., and Hellner, E., 1973. Die Fraktionierung des Sauerstoffisotops ${ }^{16} \mathrm{O}$ und ${ }^{18} \mathrm{O}$ im System Magnetit/Wasser: Fortschr. Mineral., v. 50, p. 32-33.

Clayton, R.N., and Mayeda, T.K., 1963. The use of bromine pentafluoride in the extraction of oxygen from oxides and silicates for isotopic analysis: Geochim. Cosmochim. Acta, v. 27 , p. $43-52$.

Epstein, S. and Taylor, H.P., 1970. ${ }^{18} \mathrm{O} /{ }^{16} \mathrm{O},{ }^{30} \mathrm{Si} /{ }^{28} \mathrm{Si}, \mathrm{D} / \mathrm{H}$, and ${ }^{13} \mathrm{C} /{ }^{12} \mathrm{C}$ studies of lunar rocks and minerals: Science, v. 167, p. $533-535$.

O'Neil, J.R. and Taylor, H.P., 1967. The oxygen isotope and cation exchange of feldspars. Am. Mineral., v. 52, p. 1414-1437.

Onuma, N., Clayton, R.N., and Mayeda, T.K., 1970. Oxygen isotope fractionation between minerals and an estimate of the temperature of formation: Science, v. 167, p. 536-538.

Taylor, H.P., 1968. The oxygen isotope. Geochemistry of igneous rocks: Contrib. Mineral. Petrol., v. 19, p. 1-71. 
S. HOERNES, H. FRIEDRICHSEN

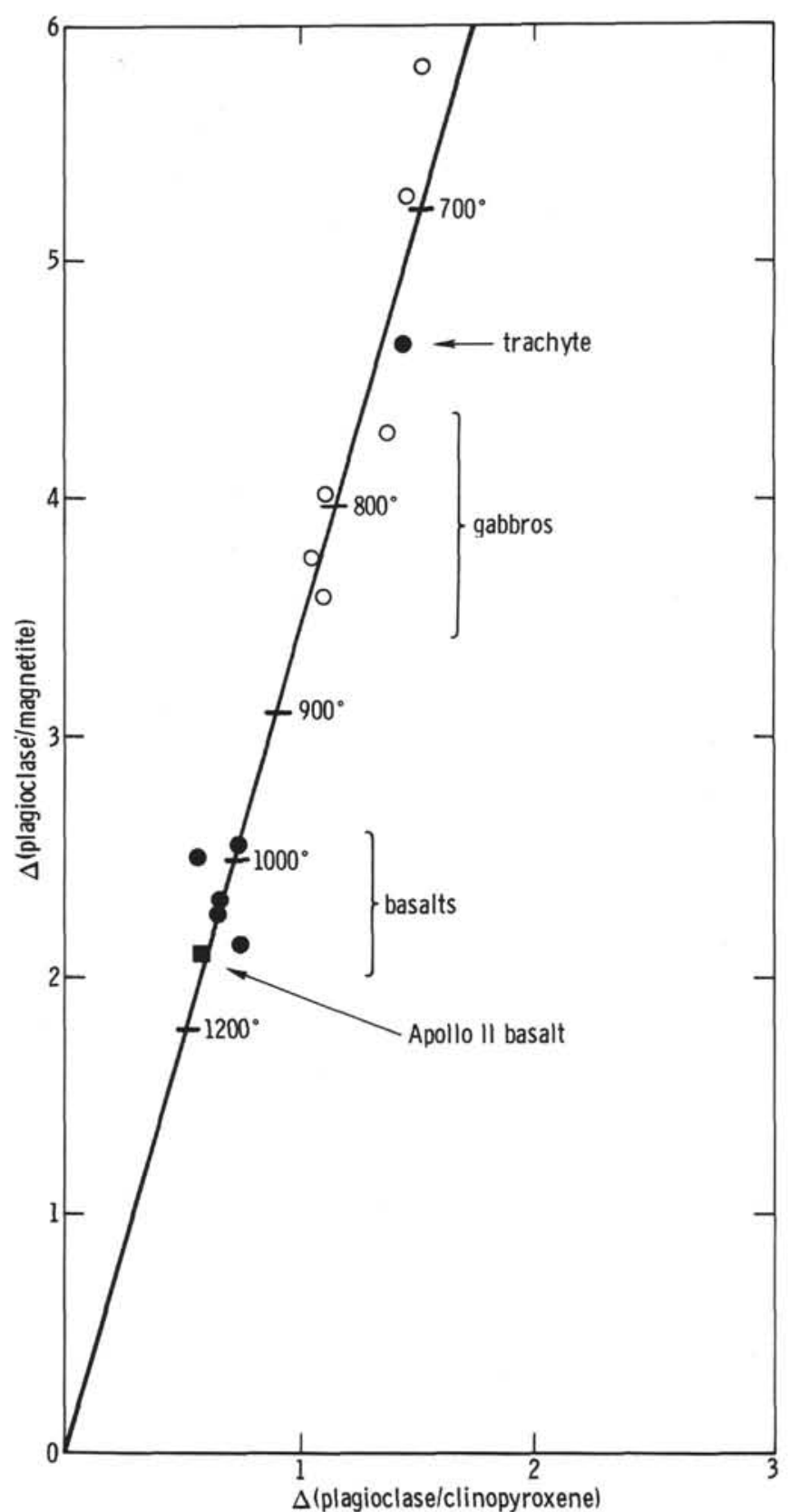

Figure 2. "Corcordancy diagram" after Anderson et al. (1971) with temperatures from the magnetite-water curve of Bertenrath (1973). 